\title{
Use of Oil Palm Bunch and Plantain Peel Extracts as Alternative Stimulants in Crude Oil Bioutilization by Species of Bacillus and Pseudomonas
}

\author{
Lawrence Bassey Etim \\ Department of Microbiology, Faculty of Biological Sciences, Cross River University of Technology, Calabar, Nigeria \\ Email address: \\ lawetim54@gmail.com \\ To cite this article: \\ Lawrence Bassey Etim. Use of Oil Palm Bunch and Plantain Peel Extracts as Alternative Stimulants in Crude Oil Bioutilization by Species \\ of Bacillus and Pseudomonas. International Journal of Microbiology and Biotechnology. Vol. 4, No. 2, 2019, pp. 45-48. \\ doi: 10.11648/j.ijmb.20190402.13
}

Received: May 9, 2019; Accepted: June 10, 2019; Published: July 2, 2019

\begin{abstract}
The potentials of oil palm bunch and plantain peels extracts in the enhancement of crude oil utilization by Bacillus and Pseudomonas species were evaluated. The average concentration of nutrients obtained from the extracts was: $\mathrm{Mg}=$ $20.4 \mathrm{mg}, \mathrm{N}_{2}=20.7 \mathrm{mg}, \mathrm{K}=63.5 \mathrm{mg}, \mathrm{Ca}=480.5 \mathrm{mg}, \mathrm{P}=276.5 \mathrm{mg}$ and $\mathrm{Na}=106.5 \mathrm{mg}$, at $\mathrm{pH} 6.6$ to 8.1 oil palm bunch extract was a better stimulant than plantain peel in the order; MSM $>$ OPB $>$ PP at a correlation of $r=0.55$. After 24 hours of incubation, bacillus-LSI utilized the crude oil for carbon and energy better in MSM (91.4\%), OPB (52.9\%) and PP (50.5\%) than Pseudomonas-LSI with $82.6 \%, 49.4 \%$ and $41.5 \%$ respectively. The difference in utilization between these test organisms is significantly positive at $\mathrm{p}>0.05$. Generally, the result imply that organic extract of oil palm bunch and plantain peel are excellent stimulants to crude oil hydrocarbon degrades relative to MSM as control and can be deployed in a cleanup campaign of oil involving less than $10 \%$ pollution level in soil and aquatic ecosystems.
\end{abstract}

Keywords: Organic Wastes, Nutrient Augmentation, C: N Ratio, Microbial Oxidation

\section{Introduction}

Occurrence of crude oil hydrocarbon pollution is on the increase in the Niger Delta region of Nigeria. Several remediation campaign strategies often deployed include mechanical, chemical and microbiological technologies [12]. In this region bioremediation technologies are considered most effective, inexpensive and easy to apply in aquatic environment.

However, bioremediation of oil pollution in natural ecosystems is complex and slow [3]. The rate depends on the chemical composition of the petroleum hydrocarbon, the presence of hydrocarbonoclastic microorganisms, and nutrient availability especially nitrogen and phosphorus [46]. Nutrient availability is a critical factor in bioremediation campaign especially in aquatic ecosystem [3]. However, nutrient augmentation exercise for effective remediation, in this environment appears a difficult task and expensive [7-8]. Therefore, augmentation exercise follows a regime of inorganic fertilizer application.
The extracts of oil palm bunch and plantain peel have been reported to contain a high concentration in the extracts are high enough to stimulate and sustain the growth of microbial population in soil and aquatic environments [9].

Oil palm tree (Elaeis guinensis) and plantain (Musa paradisiaca) are plants commonly found in the tropics. In Nigeria, the plants are grown in small family holdings and plantations along the forest belt of the south. Consequently, this study was aimed at evaluating the potentials of oil palm bunch and plantain peels extracts as supplements for enhancing crude oil bioremediation by Bacillus and Pseudomonas species.

\section{Materials and Methods}

\subsection{Collection of Materials}

The light crude oil sample used in this study was collected from Qua Iboe Terminal of Exxon Mobil Production, Nigeria Unlimited, Ibeno, Akwa Ibom State, Nigeria.

Oil palm bunch and plantain peels were obtained from 
Ibiae oil palm Estate, Ibiae and a local farmyard in Calabar, respectively, Bacillus $\left(4.1 \times 10^{6} \mathrm{cfuml}^{-1}\right)$ and Pseudomonas $\left(6.8 \times 10^{6} \mathrm{cfuml}^{-1}\right)$ species were obtained from the Department of Microbiology, Cross River University of Technology, Calabar, Nigeria.

Mineral salt medium (MSM) as compounded by TitanBiotech: $\mathrm{K}_{2} \mathrm{HPO}_{4}(1.8 \mathrm{~g}), \mathrm{NH}_{4} \mathrm{Cl}(4.0 \mathrm{~g}), \mathrm{KH}_{2} \mathrm{PO}_{4}(1.2 \mathrm{~g})$, $\mathrm{MgSO}_{4} 7 \mathrm{H}_{2} \mathrm{O}(0.2 \mathrm{~g}), \mathrm{NaCI}(0.1 \mathrm{~g}), \mathrm{FeSO}_{4} .7 \mathrm{H}_{2} \mathrm{O}(0.01 \mathrm{~g})$ in one litre of water.

\subsection{Preparation of Extract Solutions}

Samples of oil palm bunch (OPB) and plantain peel (PP) were air dried and weighed separately. They were burnt openly at $120^{\circ} \mathrm{C}$ in a furnace. On cooling, the ashes collected were again weighed. Then $37.4 \mathrm{~g}$ of ash from OPB and PP respectively were dissolved in $1000 \mathrm{ml}$ sterile deionized water. Each sample (ash solution) was filtered using a stag of No. 1 Whatman filter paper repeatedly until clarity was obtained and stored under room temperature $\left(28 \pm 2^{\circ} \mathrm{C}\right)$ for qualitative analysis.

\subsection{Determination of Physicochemical Properties of Extracts}

The $\mathrm{pH}$ of the extracts were determined using a $\mathrm{pH}$ meter and turbidity/optical density (OD) ascertained with microprocessor turbidity meter [10]. The quantitative analyses of the elements $\left(\mathrm{Ca}, \mathrm{Mg}, \mathrm{Na}, \mathrm{K}, \mathrm{N}_{2}\right.$ and $\mathrm{P}$ ) were done using atomic absorption (model 21VGP). In this method, digested sample solutions were aspirated and atomized at various wavelengths while $\mathrm{N}_{2}$ was determined using Kjedhal technique. In Kjedhal technique, sample solutions were digested, distilled and titrated to obtain the $\mathrm{N}_{2}$ values.

\subsection{Determination of Crude Oil Bioutilization Rate}

Bioutilization rate was determine using gravimetric method [11]. In this method, an 18 hour-culture of Pseudomonas and Bacillus were used.

The mean differences were compared for statistical significance using Fischer's least significant differences of means (5\% level), and correlation at $\mathrm{p}=5 \%$ [12].

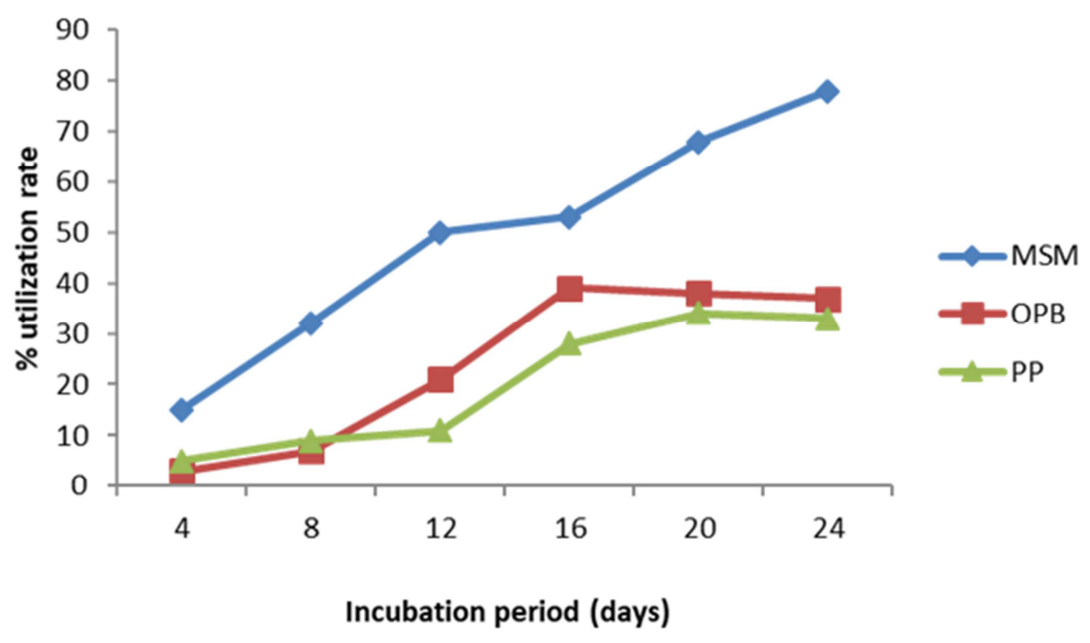

Oil enhance by organic extracts OPB and PP, MSM served as control.

Figure 1. Bacillus- LS1 bioutilization percentage of crude.

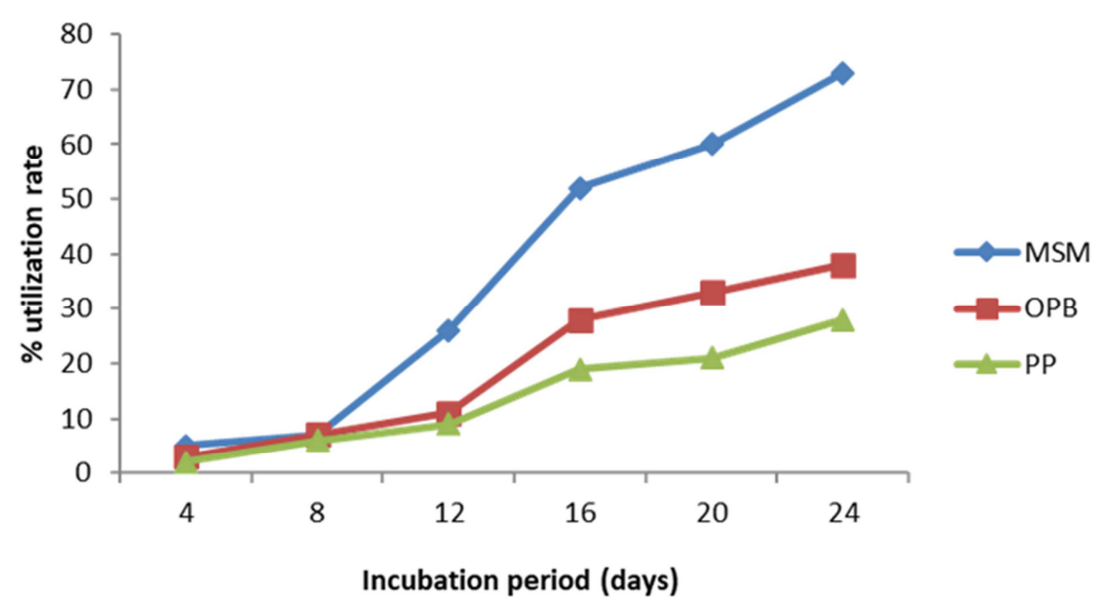

Oil enhance by organic extracts OPB and PP. MSM served as control.

Figure 2. Pseudomonas- LS2: bioutilization percentage of crude. 


\section{Results}

The oil palm bunch and plantain peel extracts are presented in tables 1 and 2. The oil palm bunch and plantain peel contained micronutrients and macronutrients in varying concentrations. Oil palm bunch has a higher concentration of potassium $(90 \mathrm{mg} / \mathrm{ml})$ and nitrogen $(31 \mathrm{mg} / \mathrm{ml})$ than plantain peel. However, in sharp contrast, OPB also recorded much less concentration of magnesium, sodium, phosphorus and calcium with values of $19 \mathrm{mg} / \mathrm{ml}, 43 \mathrm{mg} / \mathrm{ml}, 13 \mathrm{mg} / \mathrm{ml}$ and $31 \mathrm{mg} / \mathrm{ml}$ respectively compared to plantain peel with values of $21.7 \mathrm{mg} / \mathrm{ml}, \quad 170 \mathrm{mg} / \mathrm{ml}, \quad 540 \mathrm{mg} / \mathrm{ml}$ and $930 \mathrm{mg} / \mathrm{ml}$ respectively as shown in Table 1 . The $\mathrm{pH}$ range and turbidity levels of the extracts compared to mineral salt medium are presented in Table 1. The extract OPH, PP and MSM had a $\mathrm{pH}$ of $6.6,8.1$ and 7.4 and turbidity of $0.039 \mathrm{~nm}, 0.132 \mathrm{~nm}$ and
$0.044 \mathrm{~nm}$ respectively. Figures 1 and 2 show the Bacillus LSI and Pseudomonas -LS2 crude oil utilization rates in organic (OPB and PP) extracts and mineral salt medium (MSM) as control as their source of energy, metabolism and carbon respectively. Their utilization rates increase correspondingly to the increase in incubation period. Indeed, the rates (percentages) of utilization was significantly higher $(p<$ 0.05 ) in response to increase in incubation period for both Pseudomonas and Bacillus. In addition, significantly lower percentage utilization of crude oil was recorded for Pseudomonas than period of study. Bacillus in the control (MSM) compared with OPB and PP throughout. The order of enhancement by the organic extracts as stimulant follows thus: $\mathrm{MSM}>\mathrm{OPB}>\mathrm{PP}$ and significant at $\mathrm{p}<0.05$ and a correlation factor of $\mathrm{r}=0.55$.

Table 1. Physicochemical properties of oil palm bunch and plantain peel extracts (mg/I).

\begin{tabular}{lll}
\hline Extracts & Turbidity (optical density) (450nm) & pH \\
\hline Oil Palm bunch & 0.039 & 6.6 \\
Plantain peel & 0.132 & 8.1 \\
Mineral salt medium (control) & 0.044 & 7.4 \\
\hline
\end{tabular}

Table 2. Chemical composition of oil palm bunch and plantain peel extracts ( $\mathrm{mg} / \mathrm{I})$.

\begin{tabular}{lllllll}
\hline Extracts & $\mathbf{M g}$ & $\mathbf{N a}$ & $\mathbf{K}$ & $\mathbf{P}$ & $\mathbf{C a}$ & $\mathbf{N}$ \\
\hline Oil palm bunch & $19 \pm 0.20$ & $43 \pm 0.6$ & $90 \pm 0.01$ & $13 \pm 0.06$ & $31 \pm 1.01$ & $31 \pm 0.22$ \\
Plantain peel & $21.7 \pm 1.41$ & $170 \pm 2.8$ & $37 \pm 0.90$ & $540 \pm 4.1$ & $930 \pm 2.1$ & $10.3 \pm 0.18$ \\
Average & 20.35 & 106.5 & 63.5 & 276.5 & 480.5 & 20.65 \\
\hline
\end{tabular}

\section{Discussion}

The mineral composition of the organic extracts from OPB and PP significantly enhanced the microbial growth in the oil-polluted media. This observation agreed with studies as earlier reported [13-14]. The results obtained and those earlier reported indicate that the presence and adequate concentrations of nitrogen and phosphorus are critical factors in maximal microbial oxidation of crude oil hydrocarbon. Adequate nutrients support the growth of microorganisms especially in remediation campaign when the microbes are stressed from oil contaminant [15]. However, other reports demonstrated that petroleum hydrocarbon significantly reduce the availability of plant nutrient in soil [16]. The low nutrient in the environment occurs as a result of nitrogen and phosphorus content in petroleum hydrocarbon. Therefore, as microorganisms degrade the hydrocarbon, they immobilize available nutrient (i.e. $\mathrm{N}_{2}$ and $\mathrm{P}$ ) creating deficiencies in contaminated aquatic environment.

Therefore the OPB and PP extracts enriched the hydrocarbon polluted water with $\mathrm{N}_{2}$ and $\mathrm{P}$ that enhanced the oil degradation and improved the $\mathrm{C}: \mathrm{N}$ ratio.

The $\mathrm{pH}$ of the organic extracts (OPB and PP) is considered an excellent factor that enhances the utilization potential of the test organisms. Earlier studies conducted reported that optimal biodegradation of crude oil by species of Pseudomonas was obtained at $\mathrm{pH}$ range of 6.7 to 7.4 while that of Bacillus was at a range of 7.0 to 8.4 in soil and aquatic ecosystems respectively [17].
Therefore the slightly acidic to alkalinic constitution of the extract promoted the efficiency in rates of crude oil bioutilization. Results also revealed that Pseudomonas-LS2 and Bacillus-LS1 utilized approximately 52\%, 50\% and 91\% of crude oil compared to Pseudomonas-LS2 with $49 \%, 41 \%$ and $82 \%$ in the organic extract OPB, PP and MSM respectively. These differences between Bacillus species and Pseudomonas species are significant at $\mathrm{p}>0.05$. The result agrees with an earlier report by Jidere and Akamigbo [18]. In their report they stated that approximately $51 \%$ crude oil bioutilization was obtained after 20 days of incubation by Bacillus strains (28A and 61B) in an organic nitrogenous source. Notably too, the mineral salt medium (MSM) proved to be a better supplement followed by oil palm bunch and plantain peel extracts. Correlation analysis of the stimulating potential of these extracts and mineral salt medium was positive at $r=0.55$. The study therefore affirmed that the presence and concentration of $\mathrm{N}_{2}$ and $\mathrm{P}$ are critical in oil spill bioremediation campaign. Similar result was reported by Jidere and Akamigbo and Akamigbo and Jidere [18-19]. These authors stated that sufficient nitrogen and phosphorus are required to balance the available hydrocarbon in order for microbial growth and hydrocarbon reduction to occur. Equally Miller and Douahul reported that lack of organic source of readily utilizable nitrogen and phosphorus might limit growth of microorganisms and hence crude oil degradation in soil [20]. Consequently, this could be attributed to quick net nitrogen mineralization of OPB than $\mathrm{PP}$. Therefore, $\mathrm{PP}$ narrow $\mathrm{C} / \mathrm{N}$ ratio decomposed slowly than 
OPB because it lack sufficient nitrogen for microbes to increase in population [21]. Consequently, addition of OPB and PP extracts and other similar materials yet to be investigated are excellent substitutes for organic fertilizer as sources of $\mathrm{N}_{2}$ and $\mathrm{P}$ in oil bioremediation campaign. Also, the seeding of Bacillus-LS1 and Pseudomonas-LS2 in a controlled $\mathrm{pH}$ of 6.0-8.0 will accelerate degradation process in $5-10 \%$ crude oil pollution remediation campaign.

\section{Conclusion}

This study was aimed at assessing the potentials of locally sourced and available organic wastes (plantain peel and oil palm bunch) rich in nutrients as alternative to the use of inorganic nutrients (MSM) as supplements for the remediation of crude oil contaminated environment. Secondly, this study clearly demonstrated that if suitably developed, application of indigenous microorganisms can be used to remediate soil already made deficient of nutrients as a result of petroleum hydrocarbon spillage. Although MSM performed better in terms of THC percentage degradation, PP and OPB showed high potentials for remediation of crude oil contamination. However, the environmental friendliness of PP and OPB should be the basis of preference to inorganic materials in crude oil remediation campaign. The findings of this study suggested that plantain peels and palm old bunch wastes could be a potential cheap natural source of nutrients for microorganisms and could have greater importance as alternative stimulant in petroleum hydrocarbon bioremediation.

\section{References}

[1] Cox, G. V. and E. B. Cowell, (1979). Mitigating oil spill Damage-ecologically responsible Clean-up techniques. Proceeding of the Mitigation Symposium: A National Workshop on Mitigating Losses of Fish and Wildlife Habitats, July 16-20, Colorado, pp: 121-128, http://mdl.csa.com/partners/viewrecord.php?requester=gs\&col lection $=$ ENV\&recid=800419225269 con.

[2] Etim, L. B., S. P. Antai and G. Iwatt, (2007). Crude oil degradation potentials of fresh water bacterial isolate from slow running freshwater system located in Cross River State, Nigeria Global J. Pure Applied Sci., 13: 403-409.

[3] Prince, R. C., (1993). Petroleum spills bioremediation in marine environment. Critical Rev. Microbiol., 19: 217-242. PMID: 8305136.

[4] Atlas, R. M. (1981). Microbial degradation of petroleum hydrocarbons: An environmental perspective. Microbial review 45: 180-209.

[5] Jordan, R. E. and J. R. Payne, (1990). Fate and Weathering of Petroleum Spills in the Marine Environment: A literature Review and Synopsis. Ann Arbor Science, Michigan, USA, pp: 55-91.

[6] Ikpeme, E. M., J. F. Nfongeh and L. Etim, (2007). Comparative bioremediation enhancement procedures on kerosene polluted ultisol from a Nigeria Delta region, Southern, Nigeria, ResMicrobiol., 2: 856-860.
[7] Itah, A. Y. and J. P. Essien, (2001). Petroleum hydrocarbon degrading capabilities and growth profile of bacteria from crude oil polluted ultisol and brackish water. Global J. Pure Applied Sci., 7: 507-512.

[8] Itah, A. Y. and J. P. Essien, (2005). Growth profile and hydrocarbonoclastic potential of microorganisms isolated from tarballs in the Bight of Bonny, Nigeria. World Journal of Microbiology and Biotechnology, 21: 1317-1322.

[9] Osagie, A. U. and A. O. Onigbinde., (1998). Effect of Growth Maturation and storage on the composition of plant foods in: Nutritional Quality of plant foods, Osagie, A. U. and O. U. Eka (Eds.). University of Benin, Nigeria, pp: 199-220.

[10] Okpokwasili, G. C. and B. B. Okorie, (1988). Biodeterioration potentials of microorganism isolated from car engine lubricating oil. Tribiol. Int., 21: 215-220 doi: 10.1016/030167x (88) 90020-5.

[11] Venosa, A. D., M. Kadkhodayan, D. W. King, B. A. Wrenn and J. R. Haines et al., (1993). Testing the efficacy of oil spill bioremediation products. Proceedings of the 1993 International Oil spill conference. March 29-April 1, American petroleum Institute, Washington, D. C. pp: 487-494.

[12] Obi, I. U., (1986). Statistical Methods of Detecting differences between Treatment means. SWAP press Ltd, Enugu, Nigeria. P: 45 .

[13] Atlas, R. M. and R. Bartha, (1992). Fate and effects of polluting petroleum in the marine Environment. $A d v$. Microbial Ecology, 18: 1851-1855.

[14] Atlas, R. M. (1988). Biodegradation of Hydrocarbon in the Environment. In: Environmental Biotechnology Reducing Rish from Environmental Chemicals through Biotechnology, Omenn, G. S. (Ed). Plenum Press, New York, PP: 211-222.

[15] Van Hamme, J. D., A. Sigh and O. P. Ward. (2003). Recent Advances in petroleum Microbiology Microbial Molec. Biol. Rev. 63 (4): 503-549.

[16] Odokima, L. O. and M. N. Inor, (2002). Nitrogen fixing bacteria enhanced bioremediation of crude oil polluted soil. Global journal of pure and Applied Science. 8 (4): 455-468.

[17] Thompson, O. A., D. C. Wolf, J. D. Mattice and G. J. Thoma, (2008). Influence of nitrogen addition and plant root parameters on phytoremediation of pyrene-contaminated soil. Water Air soil Pollut., 189: 37-47.

[18] Jidere, C. M. and F. O. R. Akamibo, (2009). Hydrocarbon degradation in poultry droppings and cassava peels-amended typicpaleustults in SoutheasternNigeria. J. Trop. Agric. Food Environ. Extension, 8: 24-40.

[19] Akamigbo, F. O. R. and C. M. Jidere, (2002). Carbon-nitrogen dynamics in organic wastes -amended crude oil polluted wetland soil. Journal of Tropical Agriculture, Food, Environment and Extension. 3: 20-26.

[20] Miller, R. W. and R. I. Douahul, (1992). Soils: An introduction to Soils and Plant Growth $6^{\text {th }}$ Edn., Prentice Hall of India Private press, New Delhi, India, pp: 188-189.

[21] Jorgansen, K. S., J. Puustinen and A. M Suortti, (2000). Bioremediatioin of petroleum hydrocarbons-contaminated soil by composing in biopiles. Environ. Pollut., 107: 245-254. 